\title{
PENAPISAN SENYAWA BIOAKTIF PADA SIPUT LAUT GONGGONG (Laevistrombus turturella) ASAL BINTAN
}

\author{
Lily Viruly ${ }^{1,2}$, Nuri Andarwulan ${ }^{\star 2,3}$, Maggy T.Suhartono ${ }^{3}$, Mala Nurilmala ${ }^{4}$ \\ ${ }^{1} J u r u s a n$ Teknologi Hasil Perikanan, Fakultas Ilmu Kelautan dan Perikanan, \\ Universitas Maritim Raja Ali Haji, Jalan Politeknik Senggarang, Tanjungpinang, Kepulauan Riau 29100 \\ ${ }^{2}$ South East Asia Food Agricultural Science and Technology (SEAFAST) Center, Kampus IPB Darmaga, \\ Jalan Ulin, Bogor 16680 \\ ${ }^{3}$ Departemen Ilmu dan Teknologi Pangan, Fakultas Teknologi Pertanian, Institut Pertanian Bogor, Kampus \\ IPB Darmaga, Jalan Lingkar Akademik, Bogor 16680 \\ ${ }^{4}$ Departemen Teknologi Hasil Perikanan, Fakultas Perikanan dan Ilmu Kelautan, Institut Pertanian Bogor, \\ Kampus IPB Darmaga, Jalan Agatis, Bogor 16680 \\ *Korespondensi: andarwulan@yahoo.com \\ Diterima: 10 Oktober 2018/Disetujui: 22 Juni 2020
}

Cara sitasi: Viruly L, Andarwulan N, Suhartono MT, Nurilmala M. 2020. Penapisan senyawa bioaktif pada siput laut gonggong (Laevistrombus turturella) asal Bintan. Jurnal Pengolahan Hasil Perikanan Indonesia. 23(2): 206-214.

\begin{abstract}
Abstrak
Siput laut gonggong asal Bintan merupakan salah satu gastropoda laut yang belum dimanfaatkan secara optimal. Siput ini merupakan makanan laut khas Bintan dan harganya sangat mahal. Secara empiris, siput ini dipercaya dapat meningkatkan stamina dan vitalitas. Tujuan penelitian ini adalah untuk melakukan penapisan senyawa bioaktif pada siput laut gonggong asal Bintan yaitu aktivitas antioksidan dan aktivitas antimikroba. Aktivitas antioksidan dianalisis menggunakan metode DPPH dan aktivitas antimikroba dianalisis menggunakan metode difusi sumur. Aktivitas antioksidan ekstrak gonggong bercangkang tipis dengan $\mathrm{IC}_{50} 1.433,08 \pm 0,01 \mathrm{ppm}$ lebih tinggi daripada gonggong bercangkang tebal dengan $\mathrm{IC}_{50}=$ $2.051,55 \pm 0,10 \mathrm{ppm}$. Aktivitas antimikroba pada ekstrak gonggong lebih baik pada bakteri Gram positif daripada bakteri Gram negatif. Ekstrak gonggong rebus bercangkang tebal memiliki aktivitas antimikroba yang paling tinggi dengan nilai rata-rata diameter daya hambat (DDH) yaitu $25,53 \pm 0,12 \mathrm{~mm}$.
\end{abstract}

Kata kunci: aktivitas antioksidan, aktivitas antimikroba, gastropoda, gonggong

\section{Bioactive Compound Screening of Gonggong Snail (Laevistrombus turturella)}

\begin{abstract}
The Bintan gonggong snail is one of the marine gastropods that has not been optimally utilized. This snail is a typical Bintan seafood and of expensive price. Empirically, this snail is believed can increase stamina and vitality. The purpose of this study was to screen bioactive compounds in gonggong snails from Bintan, including antioxidant and antimicrobial compounds. The antioxidant activity was analyzed using the DPPH method and the antimicrobial activity was analyzed using the diffusion well method. The antioxidant activity in thin-shelled gonggong extract $\left(\mathrm{IC}_{50}=1,433.08 \pm 0.01 \mathrm{ppm}\right)$ was higher than in thick-shelled gonggong $\left(\mathrm{IC}_{50}=2,051.55 \pm 0.10 \mathrm{ppm}\right)$. The antimicrobial activity of gonggong meat extract against Gram positive bacteria was better than against Gram negative bacteria. Thick-shelled boiled of gonggong had the highest antimicrobial activity with the inhibition zone diameter of $25.53 \pm 0.12 \mathrm{~mm}$.
\end{abstract}

Keywords: antimicrobial activity, antioxidant activity, gastropod, gonggong 


\section{PENDAHULUAN}

Beberapa komponen bioaktif sudah banyak diidentifikasi dari biota laut (Li et al. 2011). Satheeshkumar et al. (2010) telah menginformasikan lebih dari 100 paten dalam bidang farmasi berasal dari siput laut. Penelitian senyawa bioaktif peptida dari hewan laut gastropoda belum banyak diteliti sampai saat ini, terutama peptida antioksidan dan peptida antimikroba.

Siput laut gonggong adalah jenis hewan moluska dari kelas gastropoda. Siput ini mendiami hampir seluruh perairan di Provinsi Kepulauan Riau (Kepri), di antaranya di perairan Pulau Bintan, Pulau Batam, Pulau Dompak, Pulau Lingga, Pulau Karimun, dan Pulau Anambas. Siput laut Gonggong merupakan ikon Tanjungpinang, Provinsi Kepri. Umumnya siput laut gonggong diolah dengan cara direbus dengan air dan garam secukupnya, lalu dimakan langsung dalam kondisi rebus menggunakan sambal yang terbuat dari kacang (Viruly 2011). Selain itu, dewasa ini pengolahan gonggong baru sebatas kerupuk gonggong yang menjadi oleh-oleh dari Tanjungpinang, Provinsi Kepri.

Kajian mengenai siput laut gonggong belum banyak diteliti secara lebih mendalam, meskipun siput ini merupakan sejenis hewan purba yang berpotensi sebagai sumber pangan fungsional, nutraceutical dan antibiotik alami (Viruly 2019). Amini (1986) mengkaji tentang komposisi proksimat gonggong, selanjutnya penelitian seasoning alami oleh Viruly (2011); Muzahar dan Viruly (2013); dan terakhir tentang peptida antimikroba (AMPs) pada gonggong oleh Viruly (2019). Viruly (2019a dan 2019b) menyatakan bahwa daging gonggong dan hemolimfa gonggong diduga mengandung protein histon $\mathrm{H} 2 \mathrm{~A}$ yang umumnya berperan sebagai senyawa antibiotik alami pada hewan laut berupa peptida antimikroba (AMPs).

Antibiotik dari beberapa tipe dewasa ini banyak diteliti dan dikembangkan untuk keperluan klinis, namun belum cukup mengatasi laju resistensi antibiotik terhadap mikroorganisme yang menyebabkan penyakit, sehingga perlu dicari alternatif lain berupa antibiotik alami dari biota laut. Kejadian resistensi terhadap antibiotik konvensional sampai saat ini masih tinggi dan fakta ini menyebabkan banyak peneliti mengembangkan peptida antimikroba (AMPs) dari hewan moluska laut (kelas bivalva dan gastropoda). Peneliti sebelumnya melaporkan bahwa hewan laut diduga memiliki mekanisme antibiotik yang lebih baik daripada ekstrak antibiotik dari hewan darat (Duval et al. 2009; Sathyan et al. 2012). Keistimewaan mekanisme kerja peptida antimikroba dari moluska salah satunya adalah dapat membunuh mikroorganisme dalam waktu sangat singkat (mekanisme patogen-eliminasi) karena dapat berinteraksi dengan asam nukleat (mengikat DNA mikroba) dari sel mikroba, sehingga mikroba lebih cepat rusak dan mengalami kematian. Sifat membunuh atau menghambat mikroba dengan jalan merusak asam nukleatnya ini menjadikan peptida antimikroba dari moluska sulit mengalami resisten terhadap mikroba (Zoysa et al. 2009). Peptida antimikroba dari moluska laut berfungsi sebagai antimikroba dengan spektrum yang luas, yaitu memiliki mekanisme kemampuan antimikroba yang dapat berperan menghambat atau bahkan membunuh bakteri gram positif, bakteri gram negatif, fungi, khamir, virus, dan protozoa (Li et al. 2011; Zoysa et al. 2009; Namet al.2015). Penelitian peptida antimikroba (AMPs) dari hewan moluska laut ini menjadi fokus penelitian terhadap pemecahan masalah resistensi terhadap antibiotik konvensional (Yu et al. 2016).

Selain itu, perkembangan teknologi saat ini menyebabkan terjadinya peningkatan sejumlah senyawa radikal bebas dari polusi udara (asap pabrik, asap rokok, asap kendaraan bermotor, dan pembakaran hutan), stres, dan radiasi yang dapat menyebabkan tubuh manusia tidak bisa menangkal radikal bebas yang masuk ke dalam tubuhnya secara alami. Fakta ini menjadikan manusia mencari solusi untuk menangkal radikal bebas dengan mengonsumsi senyawa antioksidan dalam bentuk pangan fungsional, nutraceutical, dan farmasi (Hasan et al. 2015).

Beberapa studi pendahuluan
yang berhubungan dengan senyawa
bioaktif antioksidan dari biota laut telah
banyak dilakukan, di antaranya adalah




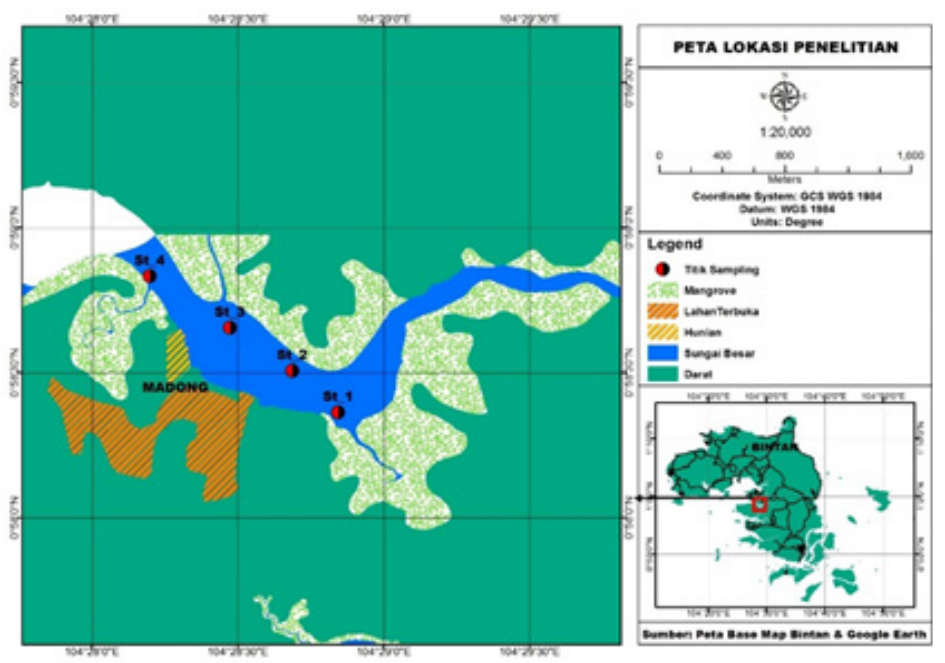

Figure 1 Location of the sampling sites

antioksidan dari siput laut Salmo fascilaria (Nurjanah et al. 2011), lintah laut (Discodoris sp.) (Nurjanah et al. 2012), biota Haliotis discus hannai Ino (Zhou et al. 2011), akar bahar (Teffu et al. 2015), kerang simping (Suptijah et al. 2013), telur keong emas (Abdullah et al, 2017), ikan buntal pisang (Pratama et al, 2014), lindur (Dia et al. 2015). Senyawa bioaktif antioksidan yang pernah diteliti sebelumnya, pada dasarnya bukan hanya senyawa bioaktif hasil metabolit sekunder saja tetapi pada siput laut aktivitas senyawa antioksidan dapat juga merupakan peptida antioksidan. Siput laut gonggong termasuk gastropoda yang diduga kuat berpotensi mengandung senyawa bioaktif peptida (antimikroba dan antioksidan). Berdasarkan informasi tersebut maka perlu dilakukan evaluasi keberadaan senyawa bioaktif peptida pada siput laut gonggong Bintan melalui analisis aktivitas antioksidan dan antimikroba.

\section{BAHAN DAN METODE Bahan dan Alat}

Penelitian ini menggunakan siput laut gonggong atau gonggong sebagai bahan utama. Bahan pendukung lainnya dalam penelitian ini adalah 1,1-difenil-2-pikrilhidrazil (DPPH), mikroba patogen yaitu bakteri E. coli (ATCC 25922) dan bakteri S. aureus (ATCC 25923) dari PTThermofisher Scientific, etanol (Merck, co), media BHI (Sigma-aldrich) dan MHA (Sigma-aldrich). Alat-alat dalam penelitian ini di antaranya shaker (IKA Jerman), vacuum rotary evaporator (IKA RV 05 basic Jerman), spektrofotometer UV-Vis-1800UV (Shimadzu, Jepang), autoklaf (ALP Jerman), inkubator (INB-400 Memert Jerman), dan ultrasonikasi (Branson 8510 Jerman).

\section{Metode Penelitian Pengambilan bahan baku}

Bahan baku siput laut gonggong (Laevistrombus turturella) dikumpulkan dari empat stasiun di Desa Madong, Pulau Bintan, Tanjungpinang, Provinsi Kepulauan Riau (Figure 1). Pengambilan siput laut gonggong dilakukan pada waktu pagi atau sore, yaitu pada saat laut surut melalui penangkapan secara langsung menggunakan tangan (dengan cara dipungut secara langsung atau menyelam). Gonggong yang digunakan pada penelitian ini merupakan gonggong yang matang gonad dengan ukuran $8,1-10,7 \mathrm{~mm}$ (Muzahar et al. 2019). Jumlah siput laut gonggong pada penelitian ini adalah 200 ekor (100 ekor gonggong bercangkang tebal dan 100 ekor gonggong bercangkang tipis).

\section{Preparasi sampel}

Daging siput laut gonggong (gonggong segar dan gonggong rebus) dikeluarkan dari cangkangnya, selanjutnya dikeringkan pada oven menggunakan suhu $55^{\circ} \mathrm{C}$ dalam waktu 24 jam. Daging yang sudah kering digerus sampai halus, selanjutnya ditimbang $6 \mathrm{~g}$ untuk diekstrak dengan metode maserasi menggunakan pelarut etanol p.a $95 \%$ sebanyak $180 \mathrm{~mL}$. Proses ekstraksi dengan 
maserasi juga dikombinasi dengan proses ultrasonikasi. Filtrat ekstrak dievaporasi untuk menghilangkan pelarutnya, sehingga pelarut etanol memisah dengan hasil ekstrak menggunakan rotary vacuum evaporator, sehingga didapatkan ekstrak kasar daging gonggong (modifikasi Ali et al. 2006 dan Nam et al. 2015).

\section{Analisis antioksidan}

Analisis antioksidan pada peneltian ini menggunakan metode antioksidan DPPH (Hanani et al. 2005). Ekstrak daging siput laut gonggong dilarutkan dalam pelarut metanol p.a 95\% menggunakan konsentrasi pada empat level sebagai berikut 200, 400, 600 , dan 800 ppm. Kontrol positifnya menggunakan BHT pada konsentrasi empat level sebagai berikut 2,4,6, dan 8 ppm. Kristal DPPH dilarutkan dengan pelarut metanol konsentrasi $1 \mathrm{mM}$ yang dilakukan pada suhu rendah dan terlindung dari cahaya matahari, sehingga diperoleh larutan DPPH $1 \mathrm{mM}$.

Larutan ekstrak daging gonggong dan BHT dengan berbagai konsentrasi, masingmasing diambil $4500 \mu \mathrm{L}$ dan selanjutnya direaksikan dengan larutan DPPH 1 mM 500 $\mu \mathrm{L}$ menggunakan wadah reaksi yang berbeda. Campuran tersebut diinkubasi menggunakan suhu $37^{\circ} \mathrm{C}$ dalam waktu 30 menit, lalu diukur nilai absorbansinya pada spektrofotometer UV-Vis menggunakan panjang gelombang 517 $\mathrm{nm}$. Blanko juga dibuat dengan mereaksikan pelarut metanol bervolume $4500 \mu \mathrm{L}$ dengan DPPH $1 \mathrm{mM}, 500 \mu \mathrm{L}$. Persen inhibisi dihitung menggunakan rumus yaitu:

$$
\text { \%inhibisi }=\frac{(\text { A blanko-A sampel }) \times 100 \%}{\text { A blanko }}
$$

Nilai konsentrasi hambat dihitung sebagai $\mathrm{IC}_{50}$ (inhibitor concentration 50\%) yaitu nilai konsentrasi sampel (larutan ekstrak daging gonggong atau antioksidan BHT sebagai kontrol positif) yang digunakan dalam mereduksi senyawa radikal bebas $(\mathrm{DPPH})$ sebanyak $50 \%$. Nilai $\mathrm{IC}_{50}$ diperoleh dari kurva persamaan linier setelah \% inhibisi diplot pada sumbu y dan nilai konsentrasi sampel pada sumbu $\mathrm{x}$.

\section{Analisis antimikroba}

Pengujian aktivitas antimikroba pada sampel ekstrak daging siput laut gonggong ini dilakukan menggunakan metode difusi sumur (modifikasi Ali et al. 2006 dan Jagessar et al. 2008), untuk tujuan penapisan awal aktivitas peptida antimikroba melalui uji sifat antimikroba. Media BHI ( $\mathrm{pH} \mathrm{7)}$ sebanyak $25 \mathrm{~mL}$ untuk tiap cawan disterilisasi, dan ditunggu sampai dingin hingga suhu $37^{\circ} \mathrm{C}$, kemudian ditumbuhkan koloni tunggal dari bakteri E. coli ATCC 25922 dan S. aureus ATCC 25923 selama semalaman pada suhu $37^{\circ} \mathrm{C}$. Fase logaritmik dipanen dengan kepadatan $108 \mathrm{cfu} / \mathrm{mL}$ kemudian diencerkan 2 kali dengan bufer fosfat pada $\mathrm{pH}$ 7,4 sehingga menjadi $106 \mathrm{cfu} / \mathrm{mL}$.

Uji aktivitas antimikroba dari ekstrak daging siput laut gonggong (gonggong segar dan gonggong rebus) sebanyak $60 \mu \mathrm{L}$ ditambahkan ke sumur dalam media MHA, kemudian diinkubasi menggunakan suhu $37^{\circ} \mathrm{C}$ selama semalam. Aktivitas antimikroba diamati berupa rata-rata diameter daerah hambatan (nilai DDH). Kontrol positif menggunakan antibiotik ampisilin dengan konsentrasi $60 \mu \mathrm{L} / \mathrm{mL}$. Pengujian dilakukan 2 kali ulangan.

\section{HASIL DAN PEMBAHASAN}

Volume ekstrak daging siput laut gonggong menggunakan etanol p.a 95\% setelah dievaporasi didapatkan $30 \mathrm{~mL}$ (Figure 2). Ekstrak ini kemudian dianalisis senyawa bioaktifnya yang dapat berfungsi sebagai peptida antioksidan dan peptida antimikroba. Analisis peptida antioksidan melalui uji sifat antioksidan menggunakan ekstrak daging gonggong segar sedangkan analisis peptida antimikroba melalui uji sifat antimikroba menggunakan ekstrak daging gonggong segar dan daging gonggong rebus.

Analisis sifat antioksidan pada penelitian ini hanya menggunakan ekstrak daging gonggong segar, karena aktivitas antioksidan sangat ditentukan oleh keberadaan asam amino metionin dan sistein. Kedua asam amino ini sangat mudah terdenaturasi dengan adanya pemanasan atau perebusan, 


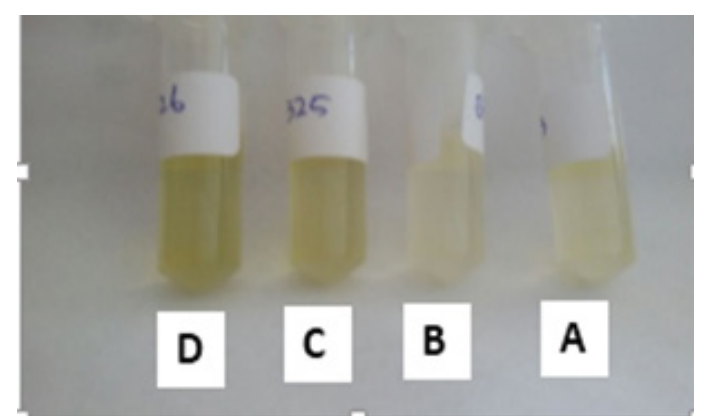

Figure 2 Gonggong meat crude extracts; (A) Thick shelled boiled gonggong meat extract;

(B) Thin shelled boiled gonggong meat extract; (C) Thick shelled fresh gonggong meat extract; (D) Thin shelled fresh gonggong meat extract

sehingga memengaruhi aktivitas antioksidan (Sabahelkheir et al. 2012; Kusumaningtyas et al. 2015).

Mekanisme antimikroba sangat ditentukan oleh keberadaan senyawa bioaktif peptida yang tersusun atas asam amino kationik (arginin, histidin dan lisin). Asam amino kationik tidak mudah terdenaturasi dalam bentuk peptida pendek (20 asam amino) (Sathyan et al. 2012; Zoysa et al. 2009). Asam amino kationik dalam bentuk peptida pendek dapat berinteraksi dengan membran sel mikroba yang bermuatan negatif sehingga dapat menghambat atau membunuh mikroba karena interaksi tersebut dapat memengaruhi permeabilitas membran sel mikroba (peptida antimikroba dapat bekerja seperti detergen) atau peptida tersebut langsung masuk ke dalam sitoplasma sel mikroba dan menghambat kerja proses sintesis DNA, RNA dan reaksi enzimatis (Jenssen et al. 2006; Mihajlovic dan Lazaridis 2010).

\section{Aktivitas Antioksidan}

Aktivitas antioksidan dievaluasi menggunakan metode DPPH dengan prinsip menangkap atom hidrogen $\left(\mathrm{H}^{+}\right)$yang merupakan donor dari antioksidan sehingga menjadikan radikal bebas dapat menurun reaktivitasnya(Kordalietal.2005). Antioksidan alami berasal dari bahan alam yaitu berupa sejenis antioksidan dari tumbuhan atau hewan yang ada di alam, contohnya: asam askorbat (vitamin C), komponen fenolik, tokoferol, kuramin dan turunan senyawa hidroksinat (Kumar 2011). Ekstrak daging gonggong segar pada penelitian ini memiliki sifat sebagai antioksidan alami, meskipun sangat lemah karena masih berupa ekstrak kasar.
Ekstrak daging siput laut gonggong segar (bercangkang tebal dan bercangkang tipis) mempunyai aktivitas antioksidan, akan tetapi ekstrak daging siput laut gonggong bercangkang tipis mempunyai mekanisme antioksidan lebih tinggi daripada ekstrak larutan daging siput laut gonggong bercangkang tebal. Hal ini ditunjukkan oleh nilai $\mathrm{IC}_{50}$ pada ekstrak daging siput laut gonggong segar bercangkang tipis yang lebih kecil, $(1.433,08 \pm 0,01 \mathrm{ppm})$ daripada nilai $\mathrm{IC}_{50}$ pada ekstrak daging siput laut gonggong segar bercangkang tebal $(2.051,55 \pm 0,10 \mathrm{ppm})$. Nilai $\mathrm{IC}_{50}$ semakin rendah menandakan bahwa mekanisme antioksidan semakin tinggi (Molyneux 2004).

Molyneux (2004) menyatakan bahwa suatu senyawa akan mempunyai mekanisme antioksidan bersifat sangat kuat jika memiliki nilai $\mathrm{IC}_{50}$ lebih kecil $50 \mathrm{ppm}$, antioksidan bersifat kuat jika nilai $\mathrm{IC}_{50}$ sebesar 50$100 \mathrm{ppm}$, antioksidan bersifat sedang jika nilai $\mathrm{IC}_{50}$ berkisar dari 100-150 ppm, dan antioksidan bersifat lemah jika nilai $\mathrm{IC}_{50}$ 150-200 ppm. Jika dibandingkan mekanisme aktivitas antioksidan pada ekstrak daging siput laut gonggong segar bercangkang tipis yaitu 1433,08 $\pm 0,01 \mathrm{ppm}$ terhadap mekanisme antioksidan dari ekstrak biota laut lainnya, maka ekstrak daging siput laut gonggong segar bercangkang tipis mempunyai mekanisme antioksidan yang lebih tinggi daripada ekstrak daging siput keong Ipong-ipong (Fasciolaria salmo) yaitu 1513,8 ppm (Nurjanah et al. 2011), tetapi lebih rendah daripada siput keong Matah Merah (Carithidea abtusa) yaitu 58,19 ppm (Purwaningsih 2012). Secara lengkap perbandingan nilai $\mathrm{IC}_{50}$ ekstrak daging 
siput laut gonggong segar bercangkang tipis terhadap beberapa biota laut dapat dilihat pada Table 1. Ekstrak daging siput laut gonggong dapat mempunyai sifat aktivitas antioksidan diduga kuat berasal dari peptidanya yang mengandung asam amino metionin dan sistein (Kusumaningtyas et al. 2015), sehingga masih perlu dilakukan penelitian lanjutan untuk menentukan asam amino penyusun peptida antioksidannya.

Senyawa peptida antioksidan pada biota laut umumnya mengandung peptida berupa asam amino histidin, arginin, lisin, glisin, prolin, leusin, alanin dan tirosin. Secara umum peptida antioksidan didominasi oleh jenis asam amino bermuatan positif (kationik) dan jenis asam amino hidrofobik (Sila dan Ali 2016). Peptida antioksidan dapat diperoleh melalui hidrolisis enzim atau dengan proses ekstraksi (Hasan et al. 2015; Sila dan Ali 2016). Jika dibandingkan dengan senyawa murni, misalnya vitamin C (3,55 ppm) (Purwaningsih 2012) atau senyawa antioksidan BHT (4,91 ppm) (Nurjanah et al. 2011) maka ekstrak daging siput laut gonggong segar bercangkang tipis memiliki aktivitas antioksidan yang masih sangat rendah, karena masih berupa ekstrak kasar bukan hasil hidrolisis protein murni, sehingga masih perlu dilakukan penelitian lanjutan.

\section{Aktivitas Antimikroba}

Mekanisme antimikroba dari ekstrak daging siput laut gonggong (gonggong segar dan gonggong rebus) dievaluasi menggunakan jenis bakteri Gram positif (Staphylococcus aureus) dan jenis bakteri Gram negatif (Escherichia coli). Mekanisme antimikroba dari ekstrak daging siput laut gonggong menggunakan bakteri Gram positif lebih baik daripada bakteri Gram negatif, dengan rata-rata diameter daerah hambatan (DDH) tertinggi pada sampel ekstrak daging siput laut gonggong rebus bercangkang tebal yaitu 25,53 $\pm 0,12 \mathrm{~mm}$ (Table 2). Kemampuan mekanisme antimikroba pada ekstrak daging siput laut gonggong rebus bercangkang tipis lebih baik pada jenis bakteri gram

Table 1 Comparison of $\mathrm{IC}_{50}$ value of gonggong meat extract to extracts of other marine species

\begin{tabular}{|c|c|c|c|}
\hline Marine Biota & $\begin{array}{c}\text { Solvent/enzyme } \\
\text { protease }\end{array}$ & $\mathrm{IC}_{50}(\mathrm{ppm})$ & Reference \\
\hline Thin shelled gonggong snail (Strombus sp.) & Ethanol & $1,433.08$ & Primary data \\
\hline Ipong-ipong snail (Fasciolaria salmo) & Methanol & $1,513.80$ & Nurjanah et al. (2011) \\
\hline Asian moon scallop (Amusium pleuronectes) & Methanol & $1,648.45$ & Suptijah et al. (2013) \\
\hline Sea urchin (Diadema savignyi) & Methanol & 3,033 & Apriandi et al. (2020) \\
\hline Sea slug (Discodoris $\mathrm{sp}$ ) & Methanol & 441 & Nurjanah et al. (2012) \\
\hline Razor clams (Solen spp) & Methanol & $1,391.08$ & Nurjanah et al. (2012) \\
\hline Papaya snail (Melo sp) & Methanol & 1,156 & Suwandi et al. (2010) \\
\hline Obtuse horn shell (Cerithidea obtusa) & Methanol & 58.19 & Purwaningsih (2012) \\
\hline Chinese mussels (Anodonta woodiana lea) & Methanol & 166.64 & Salamah et al. (2008) \\
\hline Sponge (Callyspongia sp.) & $\begin{array}{l}\text { Aceton \& } \\
\text { Methanol }\end{array}$ & 41.21 & Hanani et al. (2005) \\
\hline Bluefin Leatherjacket (Navodon septentrionalis) & $\begin{array}{l}\text { Trypsin, pepsin, } \\
\text { alkalase, papain }\end{array}$ & 5.22 & Chi et al. (2015) \\
\hline Tuna (Katsuwonus pelamis) & Neutrase & 5.00 & Je et al. (2009) \\
\hline Torpedo scad (Megalaspis cordyla) & $\begin{array}{l}\text { Pepsin, trypsin, } \\
\text { khemotrypsin, } \\
\text { pepsin }\end{array}$ & 61.1 & $\begin{array}{l}\text { SampathKumar et al. } \\
\text { (2011) }\end{array}$ \\
\hline
\end{tabular}


Table 2 Antimicrobial activities of gonggong meat extracts

\begin{tabular}{lcc}
\hline \multirow{2}{*}{ The crude gonggong meat extract } & \multicolumn{2}{c}{ Inhibition zone diameter (mm) } \\
\cline { 2 - 3 } & Gram positive (S. aureus) & Gram negative (E.coli) \\
\hline Thick shelled fresh gonggong & $21.60 \pm 0.12$ & $14.73 \pm 0.02$ \\
Thin shelled fresh gonggong & $24.52 \pm 0.02$ & $14.74 \pm 0.13$ \\
Thick shelled boiled gonggong & $25.53 \pm 0.12$ & $14.33 \pm 0.05$ \\
Thin shelled boiled gonggong & $25.05 \pm 0.15$ & $15.78 \pm 0.21$ \\
\hline
\end{tabular}

negatif daripada jenis bakteri Gram positif dengan rata-rata diameter daerah hambatan (DDH) yaitu $15,78 \pm 0,03 \mathrm{~mm}$. Perbandingan mekanisme aktivitas antimikroba antara ekstrak daging siput laut gonggong bercangkang tebal dan bercangkang tipis terhadap jenis bakteri gram positif dan jenis bakteri Gram negatif secara lengkap dipaparkan pada Table 2.

Table 2 memperlihatkan bahwa ekstrak daging siput laut gonggong rebus bercangkang tebal dan bercangkang tipis mempunyai nilai DDH mendekati sama, hal ini menjadi indikasi bahwa siput laut gonggong (bercangkang tebal dan bercangkang tipis) bisa dijadikan pangan fungsional yang mempunyai mekanisme antimikroba terhadap jenis bakteri Gram positif dan Gram negatif.

Secara umum invertebrata laut memiliki protein histon $\mathrm{H} 2 \mathrm{~A}$ yang berfungsi sebagai sistem kekebalan tubuh bawaan (innate immune) berupa senyawa peptida antimikroba (asam amino hidrofobik, pendek, kationik, sekuens mulai dari 10 hingga 50 asam amino) (Sathyan et al. 2012; Nam et al. 2015). Biota laut dari kelas gastropoda umumnya memiliki aktivitas antimikroba berupa peptida antimikroba yang tersusun atas asam amino arginin, lisin, leusin, serin, glisin, alanin, prolin dan sistein (Sathyan et al. 2012; Zoysa et al. 2009; Li et al. 2011). Hal ini menunjukkan bahwa asam amino yang bertanggung jawab sebagai peptida antimikroba berupa asam amino yang bermuatan positif (kationik) dan asam amino hidrofobik. Aktivitas antimikroba dari ekstrak daging gonggong (bercangkang tebal dan bercangkang tipis) diduga merupakan peptida antimikroba berupa peptida dari protein histon $\mathrm{H} 2 \mathrm{~A}$ (Viruly 2019a). Senyawa bioaktif peptida pada gastropoda dengan aktivitas sebagai peptida antioksidan dan peptida antimikroba pada dasarnya sangat ditentukan oleh asam amino yang bermuatan positif (kationik) dan asam amino hidrofobik (Sathyan et al. 2012; Nam et al. 2015; Sila dan Ali 2016).

\section{KESIMPULAN}

Ekstrak kasar daging siput laut gonggong segar bercangkang tipis maupun tebal memiliki antioksidan yang lemah. Aktivitas antimikroba efektif untuk bakteri Gram positif.

\section{UCAPAN TERIMA KASIH}

Penulis mengucapkan terima kasih kepada Kementerian Riset dan Teknologi Pendidikan Tinggi Indonesia atas hibah PDUPT (Penelitian Dasar Unggulan Perguruan Tinggi) Tahun 2017-2019, Direktur SEAFAST (South East Asia Food Agricultural Science and Technology) Center, FATETA IPB Bogor, dan Dekan Fakultas Ilmu Kelautan dan Perikanan, Universitas Maritim Raja Ali Haji.

\section{DAFTAR PUSTAKA}

Abdullah A, Nurjanah, Reyhan M. 2017. Karakterisasi dan identifikasi senyawa aktif ekstrak pigmen telur keong mas. Jurnal Pengolahan Hasil Perikanan Indonesia. 20(2): 286-295.

Amini S. 1986. Studi pendahuluan gonggong (Strombus canarium) di perairan pantai Pulau Bintan-Riau. Jurnal of Marine Fisheries Research. 36: 23- 29.

Apriandi A, Putri RMS, Tanjung I. 2020. Karakterisasi, aktivitas antioksidan dan komponen bioaktif bulu babi (Diadema savignyi) dari Perairan Pantai Trikora Tiga Pulau Bintan. Majalah Ilmiah Biologi Biosfera : A Scientific. 37 (1): 49-54

Chi CF, Wang B, Wang Y, Zhang YM, Deng 
SG. 2015. Purification and identification of thee novel antioxidant peptides from protein hydrolysate of Bluefin leather jacket (Navodon septentrionalis) skin. Food Research International. 73: 124-139.

Dia SPR, Nurjanah, Jacoeb AM. 2015. Komposisi kimia dan aktivitas antioksidan akar, kulit batang dan daun lindur. Jurnal Pengolahan Hasil Perikanan Indonesia. 18(2):205-219

Duval E, Zatylny C, Laurencin M, Baudy-Floch'h M, Henry J. 2009. KKKKPLFGLFFGLF: A cationic peptide designed to exert antibacterial activity. Journal Peptides. 30: 1608-1612.

Hanani E, Mun'im A, Sekarini R. 2005. Identifikasi senyawa antioksidan dalam spons Callyspongia sp. dari Kepulauan Seribu. Majalah Ilmu Kefarmasian. 2(3): 127-133.

Hasan T, Wahab AW, Djie N, Zakir M. 2015. Antioxidant activity of bioactive protein of Kerang Kepah (Atacodea striata) from South Sulawesi. American Journal of Biomedical and Life Science. 3 (6):111114.

Jagessar R, Mars A, dan Gomes G. 2008. Selective Antimicrobial Properties of Phyllanthus acidus Leaf Extract Against Candida albicans, Escherichia coli and Staphylococcus aureus Using Stokes Disc Diffusion, Well Diffusion, Streak Plate and a Dilution Method. Journal Nature and Science. 2(6): 24-38.

Je JY, Lee KH, Lee MH, Ahn CB. 2009. Antioxidant and antihypertensive protein hydrolysates produced from Tuna liver by enzymatic hydrolysis. Food Research International. 42: 1266-1272.

Jenssen H, Hamili P, Hancock REW. 2006. Peptide antimicrobial agent. Clint Microbial Rev 19: 91-511.

Kumar S. 2011. Free radical and antioxidants: human and food system. Advances in Applied Science Research. 2(1):129-135.

Kusumaningtyas E, Widiastuti R, Kusumaningrum HD, Suhartono MT. 2015. Aktivitas antibakteri dan antioksidan hidrolisat hasil hidrolisis protein susu kambing dengan ekstrak kasar bromelin. Journal Teknologi dan
Industri Pangan. 26 (2):179-188.

Kordali S, Cakir A, Mavi A, Kilic H, Yildirim A. 2005. Screening of chemical composition and antifungal and antioxidant activities of the essential olis from thee Turkish Artemisia Spesies. Journal of Agricultural and Food Chemistry. 53: 1408-1416.

Li H, Parisi MG, Parrinello N, Cammarata M, Roch P. 2011. Molluscan Antimicrobial Peptides, A Review from Activitybased Evidences to Computer-assisted Sequences. Journal International Scholarly Research. 8: 85-97.

Muzahar, Viruly L. 2013. Karakterisasi kimia, sensori dan laju pemijahan gonggong (Strombus sp.) sebagai ikon Kepulauan Riau. Jurnal Dinamika Maritim PPSPL UMRAH. 2:20-29.

Molyneux P. 2004. The use of the stable free radical dyhenylpierylhydrazil (DPPH) for estimating antioxidant activity. Journal of science and Technology. 26: 211-219.

Nam BH, Seo JK, Lee MJ, Kim YO, Kim DG, An CM, Park NG. 2015. Functional Analysis of Pacific oyster (Crassostrea gigas) $\beta$-thymosin: Focus on antimicrobial activity. Journal Fish and Shellfish Immunology. 45: 167-174.

Nurjanah, Abdullah A, Apriandi A. 2011. Aktivitas antioksidan dan komponen bioaktif keong Ipong-ipong (Fasciolaria salmo). Jurnal Pengolahan Hasil Perikanan Indonesia. 1: 22-29.

Nurjanah, Hafiluddin, Nurhayati T, Nugraha R. 2012. Nutrional and antioxidant properties of sea slug (Discorodis sp.) from Pemekasan Indonesia sea water. European Journal of Scientific Research. 79 (1): 40-47.

Nurjanah, Izzati L, Abdullah A. 2012. Aktivitas antioksidan dan komponen bioaktif kerang pisau (Solen spp). Ilmu Kelautan. 16 (3):119-124.

Mihajlovic M, Lazaridis T. 2010. Antimicrobial peptides in toroidal and cylindrical pores. Journal Biochemistry and Biophysic Acta. 1798: 1485-1493.

Pratama G, Nurjanah, Suwandi R, Jacoeb AM. 2014. Kandungan kimia, fitokimia dan toksisitas ikan buntal pisang dari kabupaten cirebon. Jurnal Pengolahan 
Hasil Perikanan Indonesia. 17(2):127-133

Purwaningsih S. 2012. Aktivitas antioksidan dan komposisi kimia keong matah merah (Cerithidea obtusa). Jurnal Ilmu Kelautan UNDIP : 39-48.

Sabahelkheir MK, Fat en MM, Hassan AA, 2012. Amino acid composition of human and animal's milk (camel, cow, sheep, and goat). ARPN Journal Science Technology. 2: 32-34.

Salamah E, Purwaningsih S, Ayuningrat E. 2008. Penapisan awal komponen bioaktif dari Kijing Taiwan (Anadonta woodiana Lea) sebagai senyawa antioksidan. Buletin Teknologi Hasil Perikanan. 11(2): 113-133.

SampathKumar NS, Nazeer RA, Jaiganesh R. 2011. Purification and biochemical characterization of antioxidant peptides from horse mackeral (Megalaspis cordyla) viscera protein. Peptides Journal. 32:14961501.

Sathyan N, Philip R, Chaithanya ER, Kumar PRA. 2012. Identification and molecular characterization of molluskin,a histoneH2A-derived antimicrobial peptide from molluscs. Review Article International Scholarly Research Network. 2012:1-6.

Satheeshkumar P, Basheer Khan A, Senthilkumar D. 2010. Marine Organisms as potential supply for drug finding-A review study. Journal of Scienties Research. 5(6): 514-519.

Sila A, Ali B. 2016. Antioxidant peptides from marine by-product:Isoaltion, identification and application in food system. A review. Journal of Fuctional Foods. 21:10-26.

Suptijah P, Nurjanah, Yanuarzki O. 2013. Aktivitas antioksidan dan komponen bioaktif kerang simping (Amusium pleuronectes). Jurnal Pengolahan Hasil
Perikanan Indonesia.16(3): 242-248.

Suwandi R, Nurjanah, Tyas FN. 2010. Aktivitas antioksidan dan komponen bioaktif dari keong pepaya (Melo sp.). Akuatik. 4(2):16-20

Teffu YH, Suwandi R, Nurjanah. 2015. Komponen kimia dan bioaktif akar bahar gorgonian (Genus Rumphella dan Hicksonella) dari Pulau Raijuanusa Tenggara Timur. Jurnal Pengolahan Hasil Perikanan Indonesia. 18(1):83-97

Viruly L, Andarwulan N, Suhartono MT, Nurilmala M. 2019a. Protein histon pada siput gonggong Bintan Strombus sp. sebagai kandidat pangan fungsional. Jurnal Ilmu dan Teknologi Kelautan Tropis. 11(1):89-101.

Viruly L, Andarwulan N, Suhartono MT, Nurilmala M. 2019b. Protein profiles and DNA isolation of hemolymph gonggong snail (Strombus sp.) from Bintan. IOP Conf. Series: Earth and Environmental Science 278.

Viruly L. 2011. Pemanfaatan Siput Laut Gonggong (Strombus canarium) Asal Pulau Bintan Kepulauan Riau Menjadi Seasoning Alami. [Tesis]. Bogor (ID): Institut Pertanian Bogor.

Yu Q, Niu M, Yu M, Liu Y, Wang D, Shi X. 2015. Prevalence and antimicrobial susceptibility of Vibrio parahaemolyticus isolated from retail shellfish in Shanghai. Journal Food Control. 60: 263-268.

Zhou DY, Zhu BW, Qiao L, Wu HT, Li DM, Yang JF, Marata Y. 2011. In vitro antioxidant activity of enzymatic hydrolysates prepared from Abalone (Haliotis discus hannai ino) viscera. Food and Bioproducts Processing. In Press.

Zoysa MD, Nikapitiya C, Whang I, Lee JS, Lee J. 2009. Abhisin: A potential antimicrobial peptide derived from histone $\mathrm{H} 2 \mathrm{~A}$ of disk Abalone (Haliotis discus discus). Journal Fish and Shellfish Immunology. 27 : 639646. 